\title{
Community-acquired lower respiratory tract infections in an adult population with HIV infection in a Nigerian tertiary hospital
}

\author{
*Odeyemi, A.O. ${ }^{1}$, Odeyemi, A. O. ${ }^{2}$, Awopeju, O. F. ${ }^{3}$, Adewole, O. O. ${ }^{3}$, Tanimowo, \\ M. O. ${ }^{4}$, Erhabor, G. E.
}

\begin{abstract}
Objective: Lower respiratory tract infections (LRTI) are 25-fold more common in people with HIV than in the general population. This study aimed to determine the prevalence of community-acquired LRTI and its associated factors in an adult population of people living with HIV (PLWH) in a Nigerian tertiary Hospital.
\end{abstract}

Methodology: This was a prospective study done at the HIV clinic of Ladoke Akintola University of Technology (LAUTECH) Teaching Hospital Osogbo, Nigeria. It involved 130 randomly selected adult participants with a confirmed HIV-positive serology. The participants were followed up for a period of one year while looking out for symptoms and signs suggestive of LRTI.

Results: The participants had a mean age of $41.9 \pm 10.02$ years and a male to female ratio of 0.4:1. Seventeen (13.9\%) of the participants developed LRTI during the study period and this was significantly associated with CD4 count and cigarette smoking history.

Conclusion: LRTI is common among PLWH in Osogbo, and it occurs more commonly in those with low CD4 T cell count and those with a history of cigarette smoking.

Keywords: Lower respiratory tract infection, HIV, pneumonia.

*Corresponding author:

Odeyemi,A.O.

Email: odeyemidamilola91@gmail.com, abiona.odeyemi@bowen.edu.ng

\footnotetext{
${ }^{1}$ Department of Medicine, College of Health Sciences, Bowen University, Ogbomoso, Nigeria.

${ }^{2}$ Department of Paediatrics, College of Health Sciences, Bowen University, Ogbomoso, Nigeria.

${ }^{3}$ Department of Medicine, College of Health Sciences, Obafemi Awolowo University, Ile-Ife, Nigeria.

${ }^{4}$ Department of Medicine, College of Health Sciences, Ladoke Akintola University of Technology, Osogbo, Nigeria.
} 


\title{
Infections des voies respiratoires inférieures acquises dans la communauté et ses facteurs associés dans une population adulte infectée par le VIH dans un hôpital tertiaire nigérian
}

\author{
*Odeyemi, A.O. ${ }^{1}$, Odeyemi, A. O. ${ }^{2}$, Awopeju, O. F. ${ }^{3}$, Adewole, O. O. ${ }^{3}$, Tanimowo, \\ M. O. ${ }^{4}$, Erhabor, G. E.
}

\section{Résumé}

Objectif de l'étude : Les infections des voies respiratoires inférieures (IVRI) sont 25 fois plus fréquentes chez les personnes séropositives que dans la population générale. Cette étude visait à déterminer la prévalence du LRTI acquis dans la communauté et ses facteurs associés dans une population adulte de personnes vivant avec le VIH (PVVIH) dans un hôpital tertiaire nigérian.

Méthode de l'étude : Il s'agissait d'une étude prospective réalisée à la clinique VIH de l'hôpital universitaire de Ladoke Akintola University of Technology (LAUTECH) d'Osogbo, au Nigéria. Il impliquait 130 participants adultes sélectionnés au hasard avec une sérologie séropositive confirmée. Les participants ont été suivis pendant une période d'un an tout en recherchant des symptômes et des signes évocateurs de LRTI.

Résultat de l'étude : Les participants avaient un âge moyen de 41,9 $\pm 10,02$ ans et un rapport homme/femme de 0,4: 1 . Dix-sept (13,9\%) des participants ont développé un LRTI au cours de la période d'étude, ce qui était significativement associé au nombre de CD4 et aux antécédents de tabagisme.

Conclusion: Le LRTI est célèbre chez les PVVIH à Osogbo, et il se produit plus fréquemment chez les personnes ayant un faible nombre de lymphocytes CD4 T et celles ayant des antécédents de tabagisme.

Mots-clés: infection des voies respiratoires inférieures, VIH, pneumonie

*Corresponding author:

Odeyemi, A.O.

Email: odeyemidamilola91@gmail.com, abiona.odeyemi@bowen.edu.ng

${ }^{1}$ Department of Medicine, College of Health Sciences, Bowen University, Ogbomoso, Nigeria.

${ }^{2}$ Department of Paediatrics, College of Health Sciences, Bowen University, Ogbomoso, Nigeria.

${ }^{3}$ Department of Medicine, College of Health Sciences, Obafemi Awolowo University, Ile-Ife, Nigeria.

${ }^{4}$ Department of Medicine, College of Health Sciences, Ladoke Akintola University of Technology, Osogbo, Nigeria. 


\section{INTRODUCTION}

Lower respiratory tract infections (LRTI) remain a major cause of mortality globally. According to the 2015 global burden of disease study, LRTI is the third leading cause of death globally, surpassed only by ischemic heart disease and cerebrovascular disease (1). Human Immunodeficiency Virus (HIV) infection is one of the risk factors for LRTI. Other risk factors include age greater than 65 years, cigarette smoking, alcohol abuse, chronic obstructive pulmonary disease, congestive heart failure and poor dental condition (2-4). Despite the gains made in the fight against Human Immunodeficiency Virus/Acquired Immune Deficiency Syndrome (HIV/AIDS), the epidemic still remains a major challenge worldwide, particularly in sub-Saharan Africa. As at the end of 2019, about 38 million people around the world were said to be living with HIV, 25.6 million of these were in sub-Saharan Africa. In the same year, 1.7 million people became newly infected with the virus worldwide and there were 690,000 AIDS related deaths (5). Nigeria has the second highest number of people living with HIV/AIDS in the world after South Africa. As at the end of 2019, about 1.8 million people were said to be living with the virus in the country (6). Approximately 44,830 people died in Nigeria of AIDS in 2019 (6).

The respiratory system is the most frequently affected organ system by HIV infection and respiratory pathology is most commonly associated with morbidity and mortality among patients living with HIV/AIDS (7). The spectrum of respiratory diseases associated with HIV infection ranges from infectious to non-infectious diseases (7). Some of the non-infectious diseases associated with HIV infection include malignancies (such as Kaposi's Sarcoma) and obstructive sleep apnoea (8). About $70 \%$ of HIV patients develop a pulmonary complication during the course of the disease, mainly of infectious aetiology (9). LRTI are 25fold more common in people with HIV than in the general population, occurring in about 90 cases per 1,000 person-years (10). Although ART has significantly reduced the incidence of opportunistic infections among PLWH $(11,12)$, LRTI, not only AIDS-related opportunistic infections, still remain a major cause of hospitalization and death among this group of people (13-15). Furthermore, community acquired Pneumonia (CAP) still remains the most frequent bacterial infection in PLWH, and it remains common even among those on ART and with high CD4 counts $(13,16,17)$.

Despite having the second highest number of people in the world with HIV/AIDS, and despite the high incidence and mortality associated with LRTI among PLWH, only a few studies have evaluated the prevalence of LRTI and its associated risk factors among PLWH in Nigeria. This study was therefore conceived with the aim of determining the prevalence of community-acquired LRTI and its associated factors in an adult population of PLWH in a Nigerian tertiary Hospital.

\section{MATERIALS AND METHODS}

Study area, study population and study design

The study was a prospective study carried out at the dedicated clinic to PLWH at Ladoke Akintola University of Technology (LAUTECH) Teaching Hospital Osogbo, Osun state. The study involved 130 randomly selected participants aged 18 to 65 years with a confirmed HIV-positive serology. Excluded were those who did not give consent, those with Diabetes Mellitus and those with pre-existing respiratory illness such as bronchial asthma, chronic obstructive respiratory disease, bronchiectasis and lung fibrosis. The participants were followed up for a period of one year from July 2015 to June 2016 while looking out for symptoms and signs suggestive of LRTI. During the follow up period the participants were seen in the clinic on a monthly basis and anytime they developed symptoms suggestive of LRTI. There was an exchange of phone numbers between the researcher and the participants (and their next of kin) to facilitate the follow up. The study objectives and procedures were explained to participants and informed consent (written and verbal) obtained. Ethical approval was obtained from the Ethics and Research Committee of LAUTECH Teaching Hospital, Osogbo with protocol number LTH/EC/2014/02/0165.

Socio-demographic and clinical data of the study participants were collected using a structured interviewer-administered questionnaire. All the study participants had a general physical examination and chest examination done at the commencement of the study, during the monthly follow up clinic visits and anytime during the study when any of the participants developed symptoms suggestive of LRTI. The weight and height were measured using a GIMA ${ }^{\circledR}$ ASTRA weighing scale with an inbuilt height meter. Baseline Chest X-ray, Full blood counts (FBC) and Erythrocyte sedimentation rate (ESR) were done for all the 
participants at the commencement of the study. A random blood glucose was also done to exclude diabetes mellitus. The CD4+ T cell count of the participants was done at the commencement of the study to assess their immune status. In addition, the participants also had Chest X-ray, FBC and ESR done anytime within the study period when they developed any symptom suggestive of lower respiratory tract infection. Sputum for GeneXpert MTB/RIF assay was also done to exclude pulmonary tuberculosis.

\section{Definition of Terms}

Standardized definitions of infection were used for infection surveillance.

Definite Pneumonia: defined by chest x-ray demonstrating new infiltrate and at least one of new or increased cough, pleuritic chest pain, fever (temperature $>37.8^{\circ} \mathrm{C}$ or at least $1.1^{\circ} \mathrm{C}$ rise from baseline), new or increased sputum production, new or changed lung examination abnormalities and respiratory rate of $>25$ cycles/minute (18). In addition to the above, patient must have any one of the following constitutional criteria including fever (as earlier defined), leucocytosis, acute change in mental status from baseline and acute functional decline in activities of daily living (18).

Probable Pneumonia: defined as in definite pneumonia but in the absence of Chest X-ray or new infiltrate on chest $X$-ray (18).

LRTI: defined as either Probable pneumonia or definite pneumonia.

\section{Cigarette smoking history}

Cigarette smoking history was positive if participants were either current cigarette smokers or former cigarette smokers. Former Smokers were defined as those who had smoked at least 100 sticks of cigarettes in their lifetime, but currently do not smoke while current smokers were defined as those who had smoked at least 100 cigarettes in their lifetime and currently smoke cigarettes every day or some days (19).

\section{Data Management and Analysis}

Data were entered into the computer and analysed using the Statistical Package for Social Sciences (SPSS) version 23.0 (SPSS Chicago Inc., IL, U.S.A). Relationship between categorical variables was determined using Chisquare and student T-test was used to compare means of independent groups. Level of significance was set at $p$-value less than 0.05 .

\section{RESULTS}

Out of the 130 participants recruited for the study, only 122 participants had their data analysed. Eight of the participants dropped out of the study, giving a dropout rate of $6.2 \%$. The participants had a mean age of $41.9 \pm 10.02$ years and a male to female ratio of $0.4: 1$. Mean duration since diagnosis of HIV and use of ART was $3.9 \pm 2.84$ years and $2.8 \pm 2.33$ years respectively. (Table 1) Seventeen (13.9\%) of the participants developed LRTI during the study period. (Table 2) The development of LRTI was significantly associated with CD4 count and cigarette smoking history. (Table 3)

\section{DISCUSSION}

Diagnosis of pneumonia is not always confirmed radiologically and this was the case in our study. Hence, we used the term LRTI to refer to both the radiologically confirmed and the nonradiologically confirmed cases (definite and probable pneumonia). The study has shown that $13.9 \%$ of a cohort of adults with HIV infection developed LRTI within one year of follow-up and this was significantly associated with low CD4 T cell count and a positive history of cigarette smoking. Our finding of $13.9 \%$ is comparable to the $14.4 \%$ observed by Lamas $\mathrm{C}$ et al. who studied a cohort of PLWH in Brazil (20). Our finding is, however, higher than the $4 \%$ observed by Benard et al (21). The reason for this difference is that while we included both the radiologically and non-radiologically confirmed cases, Benard et al. included only the radiologically confirmed cases. Radiologic evidence lags behind clinical findings suggestive of pneumonia; hence, excluding those without radiologic evidence may result into missing out some patients with pneumonia.

As expected, we also observed that development of LRTI was significantly associated with lower CD4 T cell count, as LRTI occurred in $28 \%$ of those with CD $4 \mathrm{~T}$ cell count of $<200$ cells $/ \mathrm{mm}^{3}$ as compared to $14 \%$ and $3 \%$ of those with CD4 T cell count of between 200 to 500 cells $/ \mathrm{mm}^{3}$ and $>500$ cells $/ \mathrm{mm}^{3}$ respectively. This finding is similar to those of earlier studies (22-24), and it is consistent with the already established fact that infections (including LRTI) occur more frequently in the presence of a low CD4 T cell count among people living with HIV (PLWH). This is due to the fact that CD4 T cells play a key role in achieving a regulated effective immune response to pathogens (24).

Similarly, we also found a significant association between cigarette smoking and the 
development of LRTI. This is consistent with earlier studies that have shown cigarette smoking to be associated with a high rate of pneumonia even across all strata of CD4 T cell count $(23,25)$.

Our study observed no significant association between the use of co-trimoxazole prophylaxis and the development of LRTI. This is contrary to earlier studies that have demonstrated a reduction in the frequency of LRTI and the associated mortality with the use of cotrimoxazole prophylaxis (23). The reason for this finding may be due to the fact that the patients were followed-up for only a period of one year and this may have been inadequate to demonstrate the effect of the use of cotrimoxazole prophylaxis.

\section{CONCLUSION}

This study has shown that LRTI is common among PLWH in Osogbo, Nigeria, and it occurs more frequently in those with low CD4 T cell count $\left(<200\right.$ cells $\left./ \mathrm{mm}^{3}\right)$ and those with a history of cigarette smoking. We recommend the incorporation of smoking cessation therapies into the care of PLWH and an increased surveillance for LRTI in this category of people, particularly those with a low CD $4 \mathrm{~T}$ cell count.

Acknowledgement: We thank all the patients who took part in the study. We also appreciate all staff of the HIV clinic of LAUTECH Teaching Hospital.

Conflict of Interest: There are no conflicts of interest.

\section{REFERENCES}

1. GBD 2015 Mortality and Causes of Death Collaborators. Global, regional, and national life expectancy, all-cause mortality, and causespecific mortality for 249 causes of death, 19802015: a systematic analysis for the Global Burden of Disease Study 2015. Lancet 2016; 388:1459-544.

2. Torres A, Peetermans WE, Viegi G, Blasi F. Risk factors for community-acquired pneumonia in adults in Europe: a literature review. Thorax. 2013; 68:1057-65.

3. Müllerova H, Chigbo C, Hagan GW, Woodhead MA, Miravitlles M, Davis KJ, et al. The natural history of community-acquired pneumonia in COPD patients: a population database analysis. Respir Med.2012 Aug; 106(8):1124-33.

4. Kornum JB, Due KM, Norgaard M, Tjønneland A, Overvad K, Sørensen HT, et al. Alcohol drinking and risk of subsequent hospitalisation with pneumonia. Eur Respir J. 2012; 39:149-55.

5. UNAIDS. Global HIV \& AIDS statistics - 2020 fact sheet. Available from: https://www.unaids.org/en/resources/fact-sheet (Accessed $4^{\text {th }}$ December 2020)

6. National Agency for the Control of AIDS (NACA), Federal Republic of Nigeria. 2020 Quarterly HIV Factsheet (Vol. 1). Available from: https://naca.gov.ng/2020-quarterly-hivfactsheet-vol-1/ (Accessed $4^{\text {th }}$ December, 2020)

7. Odeyemi AO. HIV/AIDS and the respiratory system. In: Asekun-Olarinmoye E.O. and Alebiosu C.O. (eds.) New insights into HIV/AIDS for students and Health care Professionals. Newcastle upon Tyne, UK: Cambridge Scholars Publishing; 2019. P. 99125.

8. Odeyemi AO, Ala AO, Ogunwobi OO, Odeyemi AO, Oni OO, Israel GM et al. Risk of Obstructive Sleep Apnea Syndrome in an adult population with HIV infection in Southwest Nigeria. NJCD 2020;2(1):79-85.

9. Miller R. HIV-associated respiratory diseases. Lancet 1996; 348: 307-312.

10. Feikin DR, Feldman C, Schuchat A, Janoff EN. Global strategies to prevent bacterial pneumonia in adults with HIV disease. Lancet Infect Dis 2004; 4: 445-455.

11. Schwarcz L, Chen MJ, Vittinghoff E, Hsu L, Schwarcz S. Declining incidence of AIDSdefining opportunistic illnesses: results from 16 years of population-based AIDS surveillance. Aids. 2013; 27:597-605.

12. Lima VD, Lourenço L, Yip B, Hogg RS, Phillips $\mathrm{P}$, Montaner JS. AIDS incidence and AIDSrelated mortality in British Columbia, Canada, between 1981 and 2013: a retrospective study. Lancet HIV. 2015; 2:e92-7

13. Søgaard OS, Reekie J, Ristola M, Jevtovic D, Karpov I, Beniowski M, et al. Severe bacterial non-aids infections in HIV-positive persons: incidence rates and risk factors. $J$ Infect. 2013 May; 66(5):439-46.

14. Grinsztejn B, Luz PM, Pacheco AG, Santos DVG, Velasque L, Moreira RL, et al. Changing mortality profile among HIV-infected patients in Rio de Janeiro, Brazil: shifting from AIDS to non-AIDS related conditions in the HAART era. PLoS One. 2013; 8:e59768.

15. Ford N, Shubber Z, Meintjes G, Grinsztejn B, Eholie S, Mills EJ, et al. Causes of hospital admission among people living with HIV worldwide: a systematic review and metaanalysis. Lancet HIV. 2015 Oct; 2(10):e438-44.

16. Feikin DR, Feldman C, Schuchat A, Janoff EN. Global strategies to prevent bacterial pneumonia in adults with HIV disease. Lancet Infect Dis. 2004 Jul; 4(7):445-55.

17. Lewden C, Drabo YJ, Zannou DM, Maiga MY, Minta DK, Sow PS, et al. Disease patterns and causes of death of hospitalized HIV-positive adults in West Africa: a multicountry survey in the antiretroviral treatment era. J Int AIDS Soc. 2014 Apr 7; 17(1):18797. 
18. Stone ND, Ashraf MS, Calder J, Crnich CJ, Crossley K, Drinka PJ, et al. Surveillance definitions of infections in long-term care facilities: revisiting the McGeer criteria. Infect Control Hosp Epidemiol. 2012 Oct; 33(10):96577.

19. Centers for Disease control and Prevention; National Center for Health Statistics. National Health Interview Survey. Available from: https://www.cdc.gov/nchs/nhis/tobacco/tobacc o_glossary.htm\#: :text=Previously $\% 20$ called $\%$ $20 \mathrm{a} \% 20 \%$ E2\%80\%9Cregular\%20smoker,in $\% 2$ 0his\%20or\%20her\%20lifetime. (Accessed $8^{\text {th }}$ December, 2020)

20. Lamas CC, Coelho LE, Grinsztejn BJ, Veloso VG. Community-acquired lower respiratory tract infections in $\mathrm{HIV}$-infected patients on antiretroviral therapy: predictors in a contemporary cohort study. Infection. 2017 December; 45(6): 801-809.

21. Bénard A, Mercié P, Alioum A, Bonnet F, Lazaro E, Dupon M, et al. Bacterial pneumonia among HIV-infected patients: decreased risk after tobacco smoking cessation. ANRS CO3 Aquitaine Cohort, 2000-2007. PLoS One. 2010
Jan 26; 5(1):e8896.

22. Chet Raj Ojha, N. Rijal, K. C. Khagendra, K. Palpasa, P. Kansakar, B. P. Gupta et al. Lower respiratory tract infections among HIV positive and control group in Nepal. Virus Dis. January-June 2015;26(1-2):77-81.

23. Hirschtick RE, Glassroth J, Jordan MC, Wilcosky TC, Wallace JM, Kvale PA et al. Bacterial pneumonia in persons infected with the Human Immunodeficiency Virus. N Engl J Med 1995; 333(13):845-851.

24. Wallace JM, Hansen NI, Lavange L, Glassroth J, Browdy BL, Rosen MJ et al. Respiratory disease trends in the Pulmonary Complications of HIV Infection Study cohort. Pulmonary Complications of HIV Infection Study Group. Am JRespir Crit Care Med. 1997; 155(1): 72-80.

25. Gordin FM, Roediger MP, Girard PM, Lundgren JD, Miro JM, Palfreeman A, et al. Pneumonia in HIV-infected persons: increased risk with cigarette smoking and treatment interruption. Am J Respir Crit Care Med. 2008 Sep 15; 178(6):630-6

How to cite this article:

Odeyemi, A.O., Odeyemi, A. O., Awopeju, O.F., Adewole, O. O., Tanimowo, M. O., Erhabor, G. E. Community-acquired lower respiratory tract infections in an adult population with HIV infection in a Nigerian tertiary hospital. Research Journal of Health Sciences, 2021, 9(2): 150-157 
Table 1: Basic characteristics of respondents

\begin{tabular}{lll}
\hline Socio-demographic profile & $\begin{array}{l}\text { Frequency } \\
(\mathbf{n}) \mathbf{n}=\mathbf{1 2 2}\end{array}$ & Percentage (\%) \\
\hline Age (in years) Mean \pm SD & $41.9 \pm 10.02$ & \\
Sex & & \\
Male & 35 & 28.7 \\
Female & 87 & 71.3 \\
BMI & & \\
Underweight & 8 & 6.6 \\
Normal weight & 84 & 68.9 \\
Overweight & 19 & 15.6 \\
Obesity & 11 & 9.0 \\
Mean duration since diagnosis (in years) & $3.9 \pm 2.84$ & \\
CD4 count (cells/mm ${ }^{3}$ ) & & \\
$<200$ & 25 & 20.5 \\
200 - 500 & 64 & 52.5 \\
$>500$ & 33 & 27.0 \\
Duration on ART (in years) Mean \pm SD & $2.8 \pm 2.33$ & \\
Currently on co-trimoxazole & & \\
Yes & 36 & 29.5 \\
No & 86 & 70.5 \\
Cigarette smoking history & & \\
Yes & 9 & 7.4 \\
No & 113 & 92.6 \\
\hline
\end{tabular}

Table 2: Occurrence of LRTI in the study participants

\begin{tabular}{lll}
\hline Variable & $\begin{array}{l}\text { Frequency (n) } \\
\mathbf{n = 1 2 2}\end{array}$ & Percentage (\%) \\
\hline Pneumonia & 4 & 3.3 \\
Probable Pneumonia & 13 & 10.7 \\
None & 105 & 86.1 \\
Development of LRTI & & \\
Yes & 17 & 13.9 \\
No & 105 & 86.1 \\
\hline
\end{tabular}


Table 3: Relationship between the patients' characteristics and the development of LRTI

\begin{tabular}{|c|c|c|c|c|}
\hline \multirow[t]{2}{*}{ Variables } & \multicolumn{2}{|c|}{ Development of LRTI } & \multirow[t]{2}{*}{ Test statistics } & \multirow[t]{2}{*}{ P-value } \\
\hline & Yes $n(\%) n=17$ & $\begin{array}{l}\text { No } n(\%) \\
n=105\end{array}$ & & \\
\hline Age (in years) Mean \pm SD & $42.9 \pm 10.08$ & $41.7 \pm 10.04$ & $t=0.456$ & 0.649 \\
\hline \multicolumn{5}{|l|}{ Sex } \\
\hline Male & $6(17.1)$ & $29(82.9)$ & \multirow[t]{2}{*}{$\chi 2=0.421$} & \multirow[t]{2}{*}{0.516} \\
\hline Female & $11(12.6)$ & $76(87.4)$ & & \\
\hline \multicolumn{5}{|l|}{ BMI $\left(\mathrm{Kg} / \mathrm{m}^{2}\right)$} \\
\hline Underweight & $3(37.5)$ & $5(62.5)$ & \multirow[t]{4}{*}{$\chi 2=4.343$} & \multirow[t]{4}{*}{0.227} \\
\hline Normal weight & $10(11.9)$ & $74(88.1)$ & & \\
\hline Overweight & $2(10.5)$ & $17(89.5)$ & & \\
\hline Obesity & $2(18.2)$ & $9(81.8)$ & & \\
\hline $\begin{array}{l}\text { Mean duration since } \\
\text { diagnosis (in years) }\end{array}$ & $3.1 \pm 2.65$ & $4.0 \pm 2.86$ & $\mathrm{t}=-1.237$ & 0.219 \\
\hline \multicolumn{5}{|l|}{ CD4 count $\left(\right.$ cells $\left./ \mathrm{mm}^{3}\right)$} \\
\hline$<200$ & $7(28.0)$ & $18(72.0)$ & \multirow{3}{*}{$\mathrm{LR} \chi 2=7.930$} & \multirow[t]{3}{*}{0.019} \\
\hline $200-500$ & $9(14.1)$ & $55(85.9)$ & & \\
\hline$>500$ & $1(3.0)$ & $32(97.0)$ & & \\
\hline \multicolumn{5}{|l|}{ Currently on *CTX } \\
\hline Yes & $5(13.9)$ & $31(86.1)$ & \multirow[t]{2}{*}{$\chi 2=0.000$} & \multirow[t]{2}{*}{0.993} \\
\hline No & $12(14.0)$ & $74(86.0)$ & & \\
\hline \multicolumn{5}{|l|}{ Cigarette smoking history } \\
\hline Yes & $7(77.8)$ & $2(22.2)$ & \multirow{2}{*}{$\begin{array}{l}\text { Fisher's exact } \\
\text { test }\end{array}$} & \multirow[t]{2}{*}{0.000} \\
\hline No & $10(8.8)$ & $103(91.2)$ & & \\
\hline
\end{tabular}

${ }^{*} \mathrm{CTX}=$ Co-trimoxazole, 